\title{
Interpretations of St. Francis of Assisi in the 20th Century: Philosophical-Anthropological Perspective*
}

\author{
Oleksandr Golozubov \\ National Technica University, Kharkiv, Ukraine
}

\begin{abstract}
The article deals with investigating and comparing key modern and postmodern interpretations of St. Francis of Assisi from a philosophical-anthropological perspective. We determine these interpretations to be as follows: a man of wonder and lover of wisdom, in other words, a true philosopher; hero of all times; defender of the poverty and poor; "champion of liberty"; peace-maker and pacifist; God's troubadour; patron of nature and animals. All of these manifestations of St. Francis' personality have been enriched by his Christocentrism and joyful vision. Moreover, this can be traced in primary sources and also echoes in the late modern period. Postmodernity not only incorporated similar motives into the cultural space with new focus and accent, but it also put forward some new visions. St. Francis was postulated as God's Fool, not so much in the medieval as in the postmodern sense of foolishness and madness as a way of interaction with the absurd and puzzle-like world in which we live. It also reconciles traditional opposition between joy and laughter as inner feelings and outward emotions within the frame of the postmodern Divine Comedy.
\end{abstract}

Keywords: modernity, postmodernity, St. Francis of Assisi

First of all, the paper is not aimed at reviewing all possible interpretations of St. Francis of Assisi published in the last century but rather those that offer something fundamentally novel in terms of accent or meanings relative to the late Middle Ages. There is a huge compendium of the hagiographic and research material allowing us draw conclusions about medieval approaches to St. Francis' image. The main of them can be listed according to the newest translation of St. Francis' writings and related texts: the saint, the founder, and the prophet (Armstrong, Hellmann \& Short, 1999-2001). There is no place here for this discussion but, possibly, the apology of radical poverty and Christocentrism are the most important features of St. Francis as medieval saint.

Thus, the material for the research summarized in this article pertain to the culture of the last century in its two main components, namely late modernity in association with the cultural and intellectual movements of the early twentieth century, and postmodernity. It should be noted that there is a wide spectrum of views on the above-mentioned terms. It is not even easy to define the chronology and nature of modernity, which, in turn, is the starting point for the postmodernity and postmodernism. Some configurations of postmodernism have been

\footnotetext{
* This paper is based on the research that was conducted during Professorial Fellowship at the Central European University in 2011/2012 academic year.

Oleksandr Golozubov, professor, Department of the Cultural Studies, National Technical University, Ukraine.
} 
hidden in modernism, such as the recognition of the pluralistic world, the rejection of metanarratives and totalizing explanations, the usage of masks, irony, anti-realism, and the search for various forms of self-presentation. In this sense according to Graham Ward: "postmodernism is both an aesthetic and a critical moment within the ideology of the modern" (Ward, 2001, p. 14). We follow Ward in his distinction between postmodernity and postmodernism and his statement that in the frame of postmodernity "cultures become weaves of ideologies, values, symbols, activities and powers" (Ward, 2001, pp. 22-23) while "postmodernism enables us to distinguish certain elements in our contemporary world which are other than postmodern and yet, all too often, can be lumped together as characteristics of postmodernity" (Ward, 2001, p. 22). Vanhoozer (2003), an editor of another anthology in the sphere of postmodern theology, treated postmodernity as a postmodern condition, which was, first of all, a set of postmodern turns in architecture, art, society, philosophy, and literary theory. So, postmodernism itself can be considered more as a philosophical and aesthetical trend and, at the same time, a way of thinking. Having been viewed as a cultural situation since 1960s, postmodernity was marked by interdisciplinary and cross-cultural manifestations. Postmodernity has formed an ideological and spiritual context to resolve various problems, which were partly anticipated and reflected in the modern epoch and announced by postmodernism in philosophy, religion, aesthetics, gender studies etc. Postmodern thinking was marked by a variety of new approaches to theology. It not only touched on Christ himself, but also some other prominent personalities in the history of the Catholic Church and, in first order, St. Francis of Assisi.

The article will provide a review of modern and postmodern interpretations of St. Francis of Assisi in the humanities and in popular culture, as well as summarize and offer a typology of their key characteristics as seen from a philosophical-anthropological perspective.

\section{St. Francis and Modernity}

First of all, it should be said that St. Francis has evoked huge interests since the first wave of new medievalism in the Romantic period and throughout the next few waves; namely, the modern and postmodern stages. Renewed interests in medieval studies in the early twentieth century was marked by a clear accent on humanism and spirituality. Martin considered medieval humanism as "one phase of Christian humanism" (McGuire, 1953, p. 398), peculiar for both new medievalism and post-modern where opposition to the industrial world was enhanced by a new component - the anthropological turn in the humanities, especially philosophy, and the whole culture of the last century.

Not surprisingly the founders of philosophical anthropology, primarily Max Scheler, revealed interests in St. Francis from the outset St. Francis's Christocentric anthropology was opposed to the anthropology of domination. Scheler in his essay "The Idols of Self-Knowledge" (Scheler, 1911) mentioned St. Francis among the "discoverers of feeling" and "enlargers of the empire' of the microcosmos", who, like Rousseau and Goethe, were distinguished by "ability to comprehend their experience in its purity" (Scheler, 1973, p. 86) or, in other words, had special vision. Later Scheler made emphasis on Saint Francis in his book The Nature of Sympathy (Scheler, 2008) as a person who "achieves an expansion of the specifically Christian emotion of love for God the Father, and for our neighbor and brother in God, to include all the lower orders of nature; while at the same time he succeeds, or seems to succeed, in uplifting nature into the light and glory of the supernatural" (Scheler, 2008, p. 87). Scheler recognized unique place of St. Francis in the Christian tradition in this sense. 
The saint of Assisi addressed to the nature not in sense of a mere parable. His relationship to nature is emotional, "is that natural objects and processes take on an expressive significance of their own without any parabolic reference to man or to human relationships generally". That is important, "he thinks of Nature as a living whole" where a single divine life is embodied. Notably, Scheler himself does not recognize St. Francis as a theologian or philosopher. His social mission reminds "though on a much smaller scale, the Buddha's campaign against the ancient Indian caste-system" (Scheler, 2008, p. 91). At the same time St. Francis can be defined as the "self-styled troubadour of God", "who kept the habit of humming his beloved French troubadour songs to himself to the end of his life, never lose to hold of this strand of his past life" (Scheler, 2008, p. 92). But a key component of the Franciscan vision was again emphasized in 1927, at a speech in Berlin where Scheler said that Franciscanism had initiated a new emotional attitude towards animals and plants, i.e. to everything in nature that is the closest to man as a living being.

This new emotional attitude meant that a new type of sainthood was required in the late Middle Ages, and in the "new Middle Ages" of the twentieth century. In their article Sabatier and Bevan (1909) wrote that St. Francis was "a Catholic of a type never seen before his time" (Sabatier \& Bevan, 1909, p. 53). Earlier in November of 1893, Paul Sabatier published his book Life of Francis of Assisi. It is well-known that this book gave a great stimulus to the study of Franciscanism and medievalism in general. Sabatier offered interpretation of St. Francis, which became the basis for further Romantic and sentimental visions of St. Francis. This meant treating feeling and emotions as religious experience and means of spiritual penetrations. This type of sainthood combined obedience to the Church with liberty of thinking and non-dogmatic religiosity. A new reading of the unorthodox saint' life could be seen primarily in Chesterton's philosophical treatises and essays. In 1923 Chesterton wrote in his book about St. Francis: "Tell it as the tale of one of the Troubadours, and the wild things he would do for his lady, and the whole of the modern puzzle disappears" (Chesterton, 2008, p. 6). Troubadours were among medieval personages who symbolise a world up-side down, the perversion of social roles and behavioural models. This human type is represented more than once in Chesterton's fiction, especially in his novels The Napoleon of Notting Hill (1904) and The Man Who was Thursday (1908). Chesterton's heroes behave like children or madmen like that are, however, the same thing, for Chesterton raises the question, asked by Swift earlier, and later again throughout twentieth-century western literature: is our world of common sense not absurd, with its established values and criteria? Perhaps, those are right who, like children, do not obey the prevailing lack of spirituality, but are still full of fresh, uncomplicated ideas and feelings that are, therefore, incomprehensible and ridiculous to others. St. Francis also touches on the carnival worldview, not in the sense of spontaneity and the destructive beginning resolutely peculiar to each carnival, but in terms of renewal and freedom, renewal towards religiosity and freedom towards spirituality.

Philosophical comprehension of the essence of spiritual gaiety and religious humour has assumed an increasingly important place in the theological reflection and various cultural paradigms in the following decades, and Chesterton's novels and essays played a significant role in this process. We can also recall phrases from some screen versions of Father Brown's stories, which don't have literal equivalent in Chesterton's original text. For example, maxims "Humor is a manifestation of religiosity" and "Devil knows how to have fun, but does not know how to joke" from the movies The Black Sheep (dir. Helmut Ashley, 1960) and The Hammer of God (dir. Robert Tronson, 1974) respectively. It corresponds with the general spirit of cheerfulness 
and optimism that is peculiar not only to both Pater Brown and St. Francis of Assisi but, obviously, to Chesterton himself. The latter of these phrases, perhaps, gives a clue regarding the attempt to enable the eternal opposition between joy and laughter in Christian traditions, which was later done in postmodernity.

This interpretation of St. Francis in the spirit of Christian humanism recalls simultaneous attempts to reform the Catholic Church from within, which were primarily initiated by modernist theologians Alfred and George L.Tyrrell. Pope Pius X condemned the changes they had proposed to the Catholic Church in the syllabus Lamentabili sane exitu (1907) and the encyclical letter Pascendi dominici gregis (1907). Nevertheless, questions of religion updates after a few decades were the focus of the Second Vatican Council. This time they were supported by a much greater part of the Catholic clergy and therefore, the interpretation of St. Francis in the spirit of Chesterton was very helpful.

In general, modern approaches to St. Francis revealed more mysticism within him, as well as more spirituality, more personality, finally overcoming the barriers between man and nature.

The saint's deep understanding of nature became also an important component of the postmodern vision of St. Francis, when theology revealed its interdisciplinary and inter-religious character at the intersection of a number of subjects in modern humanities, particularly philosophical anthropology and cultural studies.

\section{St. Francis and Postmodern Visions}

The above-mentioned approaches stimulated a great interest in the personality of St. Francis in the second half of the 20th century that was shaped by postmodernity.

St. Francis in postmodernity developed towards philosophical-anthropological interpretation especially clearly. Interest in St. Francis within philosophy in general and especially philosophical anthropology is quite natural if to consider philosophy as the ability to not only profoundly comprehend reality, but also take, surprisingly, a new look at man and the world. According to Kopaczynski, St. Francis combined in his teaching and his personality theological and philosophical wonder, and the intimacy towards nature, reverence for the mystery of Christ and the love of freedom. Not only St. Francis himself, but also some of his associates and followers present a considerable interest in this context, first of all Jacopone da Todi, a wandering ascetic, mystic and poet, and a very rare kind of holy fool of the Western world.

Kopaczynski noted that Austrian mathematician, physicist, and philosopher Friedrich Waismann had embodied his understanding of philosophy in the word "vision". Waismann referred to a new vision of things, the ability to see old things anew and familiar things in a fresh way. According to that point "if every great philosopher is guided by a sense of vision, of seeing things in new ways, St. Francis of Assisi with his new insight into the very nature of reality surely deserves to be treated by philosophers, even though he himself is not one of them" (Kopaczynski, 1990, p. 253). Kopaczynski compared this vision to the child-like world view, and it is reasonable. But philosophy is not only vision. It is inseparable from wonder, and "Saint Francis is the quintessential man of wonder" (Kopaczynski, 1990, p. 255). It is reasonable to recall that noted American author Sam Keen maintained the same view about philosophy and it helped him to ground his theology of play and the idea of a dancing God (Keen, 1970). There is theological wonder and there is philosophical wonder. But St. Francis had unitary vision, "holistic vision of all wonder beginning and ending in God as ultimate goal that we find him a perpetual philosophical spur" and this is a child-like world view also because "wonder 
begins in the child". Philosophy and theology have been combined in this approach. "The close link between philosophy and theology in the Franciscan tradition is an indisputable part of the historical record" (Kopaczynski, 1990, p. 250). So, what is St. Francis' contribution to philosophy?

(1) His love to nature leads to the development of a philosophy of nature.

(2) His love for freedom "makes his school voluntaristic".

(3) His esteem for the mystery of Christ "helps the school formulate a Christocentric doctrine", and so forth.

Undoubtedly, there is philosophical message in Franciscanism apart from theology itself, and this message has been distinctively marked by an anthropological accent. It can hardly constitute an independent philosophical school or trend but it has shaped modern and postmodern philosophy in some respects.

Thus, postmodern St. Francis is A Man of Wonder and A Lover of Wisdom and this equally connects him with the basic foundations of both philosophy and theology.

The common problematic field between theology and philosophical anthropology has been significantly developed within postmodernity. Postmodern theologian M. Fulkerson considers cultural anthropology as an important element in the postmodern theology, and theological knowledge as a set of discourses, rituals, interpretations and the practical wisdom that opened for cultural studies. Among those attempting to synthesise out theology and anthropology is Gil Bailie, the founder and president of The Cornerstone Forum-an organisation studying changes that Christians face under conditions of spiritual and moral crisis in the contemporary world. Bailie organises lectures and seminars based on anthropological approaches of Rene Girard, Henri de Lubac, John Paul II, etc. In 2007, Pope Benedict XVI stressed the importance of the efforts undertaken by Bailie. At that time, the Pope noted that interaction between theology and anthropology was a good way to substantiate uniqueness and absolute value of Christianity.

One of the thinkers who advocated this synthesis was Henri de Lubac. He defended the idea that a strong division between the natural and supernatural was artificial and that it was not grounded in Patristic and medieval theology. Man embodies the unity of both and he is oriented towards God and his revelation. Henri de Lubac supported Teilhard de Chardin in his non-orthodox position. It is interesting that one of de Lubac's writings is devoted to Joachim de Flore, who inspired some radical medieval movements, including Franciscan spirituals. Henri de Lubac himself had been criticised and oppressed by the Vatican but before the Vatican II Council Pope John XXIII invited him to participate in its preparation and the reforms that were initiated. In general John XXIII has a special place in the history of the Catholic Church. He was no ordinary person and itis not surprisingly that he announced such serious reforms in the postmodern situation. Moreover, in some respects he resembles St. Francis. There is R. Matzerath's article about it. What similarities are between St. Francis and Pope John XXIII according to Matzerath (1963)? Both had a disarming informality coupled with an acute dramatic sense; both boldly captured and vividly enchanted the imagination with their delightful vignettes of the Gospel put into literal practice; they won the love of people all over the world by their optimism, their joy, their almost boyish light-heartedness; deep concern for the needs of men; ecumenical dialogue/encountering with the men of Francis' day combined with new type of religious experience that was understanding and love of the humanity of Christ.

It could be added that Pope John XXIII had a strong sense of humour like no other other Pope before him 
(Schiffers, 1974). In St. Francis, Matzerath found all kinds of the freedom embodied in John XXIII: the spirit of freedom itself, proclaimed by Pope John at the opening of the Vatican II Council; an appeal to find new ways of expressing God's eternal truths; and openness to non-Catholics; "joyful and fruitful liberty of spirit"; principle of freedom of conscience and "freedom of truth, of duty, and of joy", "freedom to overcome all obstacles which hindered him in attaining the ideal God set before him", on the other hand. In general "St. Francis fought for and won spiritual freedom by conquering himself" (Matzerath, 1963, p. 11). This point corresponds to Political Theology by Metz (1998) and Liberation Theology by Boff (1982), the origins of which, in turn, lay in the above-mentioned religious modernism of the early twentieth century. The Catholic and protestant version of modernism sought to establish modern human experience in association with the Christian doctrine, but the "second coming" of the liberal theology in the postmodern situation was more successful. In the Dictionary of Christian Theology in 1965, liberalism is defined as the type of theological thinking, aimed at including the values of freedom, tolerance in Christian theology and humanizing motives of the contemporary Western culture. The postmodern St. Francis was also greeted by radical trends of his time. In a 1961 article, the saint was even compared to Karl Marx (Cushing, 1961). Not surprisingly St. Francis attracted liberation theologians as an apologist of poverty and in that capacity Brazilian theologian and writer Leonardo Boff described him in his book about "little poor man" of Assisi (1982). It was a manifestation of his humanity. Moreover, Boff writes that Francis "was especially gentle with the poor" (Boff, 1982, p. 23) and it reminds us a thesis of Metz that Franciscan turn to poverty was an "anthropological revolution" and meant "our attempt to achieve a new relationship to ourselves, to our natural and social environment which is not one of domination and exploitation" (Metz, 1998, p. 26). Moreover, political theology itself is rooted in "a faithfulness to being human" (Metz, 1998, p. 26). These words echo with Max Scheler's Nature of Sympathy: "we may see how freely this sacred love takes poverty upon itself as Buddha or St. Francis did” (Scheler, 2008, p. 183). Obviously, not only the category of sympathy but also the concept of empathy is proper to define St. Francis' attitude towards the poor. Under theory of an American psychoanalyst Heinz Kohut (1913-1981) it means to share feelings (such as sadness or happiness), preceding to the compassion. In Lisa M. Cataldo's opinion, St. Francis transgresses his narcissism through religious experience and empathy (Cataldo, 2007).

The current Pope Francis who became the first Pope from Latin America is sending similar emotional and social impulses to the global and post-industrial world.

St. Francis preached in the times of bourgeois activity and the emergence of towns when industrial civilisation was just being formed. Franciscans and other mendicant orders proposed a spiritual alternative to that new reality. In the same way the 1960s stimulated an optimistic outlook focused on the postmodern man, on the young generation protesting against a consumer society, who wished to live in a world, free from dictatorship, violence and injustice. Cox, one of the authors of the secularization theory, in his book Feast of Fools (1969) appealed to the early Christianity as a celebration of festivity and fantasy. Tendency marked by Metz and Jossua as Theology of Joy in the anthology under the same title (1974) has been accompanied by Theology of Laughter, represented by K. J. Kuschel, G. Aichele, Conrad M. Hyers, M.A. Screech, Robert C. Roberts, P. Laude, D. L. Miller etc.

A new joyful vision of Christianity provoked interest in the concepts of play and carnival and, accordingly, in those characters who embody the humorous world of the carnival culture, especially fools and clowns. 
It is especially interesting due to the lack of true heroes both in modern and postmodern culture. In the literature since "the lost generation", the anti-hero has dominated; heroes have been taken mainly from the past rather than the present and have been represented mainly by means of cinema (the "peplum" genre). Politicians and pop-stars have been inverted to new kind of heroes, namely celebrities, possibly not quite serious pattern of idolizing. In this context one of the postmodern versions of St. Francis can be seen as spiritual heroism and leadership, supported by rehabilitation of the Middle Ages.

According to M. Unamuno who himself was influenced by the medieval mystics heroism entails the desire for eternal life and the wish to establish one's own individualism. St. Francis's image as a hero was prepared by some points in his life and its projection into the arts. Foremost, we mean his dreams about knighthood and war stimulated by tales about King Arthur and the Knights of the Round Table in his youth, which, in turn, shaped his outlook to a certain degree. Hoch explored the image of St. Martin of Tours in the lower basilica of San Francesco in Assisi and its transformation into Chivalric Hero and Franciscan ideal (Hoch, 1987). He noted Celano used the episode with an impoverished knight to herald Francis as "a new St. Martin". In Mirror of Perfection Francis even calls his followers his "Knights of the Round Table". Chiara Frugoni (1988) defined St. Francis himself "a romantic soldier of Christ" (Frugoni, 1988, p. 122).

Maher has gone even further. According to her, St. Francis is "a hero for all times". Maher was sure that "it is now time to look again at Francis the hero" (Maher, 1978, p. 13). Under this look Francis of Assisi was represented as "a man who knew through experiential struggle in the dark chambers of his own heart how narrow and joyful is the passage to life" (Maher, 1978, p. 13). But Francis was a special kind of hero that was mad hero, "with a heart big enough to house Brother Despair along with Sister Joy" (Maher, 1978, p. 13). Moreover, it was imperative from God to be mad: he saw God "in his spirit asking him to go crazy".

But the nicest thing about Francis is that he does not abandon us to our ineptitude for real madness. He keeps showing up as the hero who walks with a Gandhi, a Martin Luther King, and Pope John XXXIII (Maher, 1978, p. 13).

Here the cross-cultural and inter-confessional context is obvious. Thus, St. Francis is

(1) A Hero For All Times (joy of victory): less compatible with the medieval vision although reminiscent of young Francis in some hagiographic writings, like T. Celano shared with modern approach:

St. Francis can also be seen as a movie star. Most known movies about him are The Flowers of Saint Francis (1950) by Roberto Rossellini; Francesco d'Assisi (1961) by Michael Curtiz; Brother Sun, Sister Moon (1973) by Franco Zeffirelli; Francesco (1989) by Liliana Cavani. Zeffirelli focuses on St. Francis' youth and simplicity, while Rossellini puts joy forward and demonstrates the humorous way St. Francis communicated with his companions, especially Brother Giovanni and Brother Juniper.

(2) Image Maker: J. Bowers supposed that "for Francis the 'godly game' was imitatio Christi. He sought to play this game so well that Christ might be discovered in the playing" (Bowers, 2009, p. 156). Besides, "Francis and early Franciscans embraced one idea of using drama and figurative images as teaching devices" (Bowers, 2009, p. 154).

So, postmodern St. Francis is a Philospher-Lover of Wisdom, Champion of Liberty, Peace Maker and Image Maker. All these interpretations are quite compatible with medieval vision and shared with modern approach. 
What other faces of the postmodern Saint Francis?

(3) God's Troubadour: compatible with the medieval vision and shared with modern medievalism; Sophie Jewett in God's troubadour (firstly was published in 1903) wrote:

One great joy remained to Francis almost until the end, the joy of being out of doors. His love for a life under the sky; his love for birds and flowers, for long journeys through the river valleys or among the high mountains, never left him.

No one laughed so merrily or sang so sweetly. (Jewett, 1957, p. 8)

Jewett did not tell stories of St. Francis' Troubadour so much as she told the story of the joyful saint.

In the postmodern situation this vision has not lost its relevance. Roger K. French even called St. Francis' time "Troubadourrean" (French, 1996, p. 35). The result of the Crusade against Cathars was "the disappearance of a medieval culture which had produced the Troubadours" (French, 1996, p. 147) and therefore the end of the Provencal culture.

It was only in 1892 when Anatole France's story Le Jongleur de Notre Dame was published. This story, in turn, was based on medieval legend and told about the monk, who had donated his tricks to the statue of the Virgin Mary. This story was told on film several times and even reproduced in music (Jules Massenet, opera $L e$ Jongleur de Notre Dame, 1902). Recently a similar plot became the basis of a short story by Paulo Coelho Our Lady's juggler. The main personage is young novice Buckhard, whose parents "were simple people, and all that they had taught him was to toss balls up in the air and do some juggling" (Coelho, 2007). When the Virgin Mary with the infant Jesus in her arms on Christmas Eve descends to earth and visits Melk Abbey, Buckhard recalls his forgotten skills and it was the key that opens Our Lady's heart and brings a smile to the face of Jesus, whom Buckhard keeps in his hands. Thus juggling is not only posted as pleasure for God and rehabilitates former clown in the eyes of the monks, but also evokes associations with the saints, who are portrayed with baby Christ in their arms, like prominent Franciscan saint Anthony of Padua. St. Francis himself has been seen as God's juggler since the Middle Ages. It is a well-known fact that this is what he called himself and his companions. At the same time there are allusions to the chivalric ideals in St. Francis' writings: "These are my knights of the Round Table".

(4) The next wide-spread interpretation is Poet and Mystic (joy of imagination), compatible with the medieval vision and shared with modern medievalism.

In the modern period St. Francis was compared, in his poetic and mystic experience, mainly to Dante (Auerbach, 1945). In postmodern literature, the poetic interpretation has interdisciplinary features. Zooey from Salinger's story Zooey is indignant because of his sister Franny. This teenager sentimentally perceives Jesus according to St. Francis' model, whose attitude to our smaller brothers corresponds more to Buddhism than to Christ's mission, who had no time to compose the hymns or to read sermons to birdies. In his opinion, Franny has one solution to her doubts and that is play.

The only thing you can do now, the only religious thing you can do, is act. Act for God, if you want to be God's actress, if you want to. What could be prettier? (Salinger, 1981, p. 198)

Jack Kerouac in his novel Dharma Bums (1958) postulated a type of Zen madman who experimented, travelled, and talked philosophically, dethroned, searched and found. St. Francis here is presented like a 
stranger who returns us to the past when people married bears and talked to buffalos.

As for last two decades A. McCann says, "the turn of the twentieth century writers seemed especially involved in the project of appropriating Francis for today's world" (McCann, 2009, p. 141). Not only Francis himself but some his companions and followers are interesting in this context, especially Jacopone da Todi, wandering ascetic, poet and mystic and kind of God's Fool at the same time (Peck, 1980).

St. Francis' theme has penetrated music as well, for example in the opera by Oliver Messiaen (1982), a French composer, organist and ornithologist. He was influenced by his Hindu and Japan experience, but his opera about St. Francis is clearly postmodernist in the sense of cross-cultural and historical referencing. The saint himself can be considered as meeting point between Eastern and Western thought and some postmodern authors investigate this issue (Tolan, 2009; Basetti-Sani, 1958).

(5) Parton of Nature and Animals (joyful experience): compatible with the medieval vision but not very typical for the modernity.

The interrelations between a man and nature and especially animals are widely represented at the Old and the New Testament. Adam gives names to the animals; Noah gathers all animals in the ark; God addresses the whale before Jonas; animals accompany certain saints permanently, for example, St. Sergius is accompanied by a bear; St. Jerome by a lion, and sometimes we see them together in extremely dangerous situations (Daniel and the lions). St. Francis perceived animals and nature not simply as some kind of background to humans, but as participants of creation. He speaks and preaches to waterfowls, swallows, crickets, lambs, worms, nightingales, doves, crows, and wolf. The archetype was St. Jeronim's taming of the lion. The story of St. Amica and the wolf, as well as St. Brendan and the birds, St. Gall and the bear should be mentioned and also St. Columban, St. Giles (St. Egidio), and finally Saint Martin. According to Severus, "it was a very ordinary thing for Martin to vanquish the fury of beasts or the venom of serpents" (Sorrell, 1980, p. 20). But mostly it was eremitic tradition that influenced St. Francis. Nevertheless, the Canticle to the Sun is original, and the originality of this hymn regarding nature is found in its language, expression and intention. These accents were not very developed in either medieval times or the modern period. St. Francis put them into a whole picture of creation, like Dante, for whom "life becomes a reading of this great book" (Lafferty, 1911, p. 32) and some kind of pantheistic or panentheistic vision combined with a joyful view of creation.

All above-mentioned dimensions have been accumulated in the image of St. Francis as JOYFUL SAINT and, firstly, this interpretation is primarily based on the medieval written sources, and, secondly, it has a clear anthropological accent.

While St. Francis' vision of full and perfect joy was most dramatically embodied in the well-known parable, there are many joyful expressions in his writings and stories about him. Christ himself was the model for this kind of joy expressed by St. Francis. Suffering isn't the good in itself. But sometimes it is a necessary and unavoidable way to the good and knowledge. Joy should be a transition mode from the human to the divine in order to transform even suffering into enjoyment. Franciscan teacher of theology James of Milan in the preface to his treatise Stimulus Amoris wrote: "How blind are the sons of Adam, who know not how to enter into Christ through these wounds! In vain they labor with all their energies, and the doors to peace are open. Or are you ignorant of the fact that Christ is the joy of the blessed?" (McElrath, 1980, p. 105) The affectation of death and suffering is replaced by the affectation of complete confluence with Christ, and then by the 
affectation of joy and happiness. A question is not about why a man doesn't want to share Christ's sufferings, but why he doesn't want to share his joy, that is culmination of these sufferings, and it gives extraordinarily emotional, sensual and partly even erotic effect to the suffering itself.

But Franciscanism embodies not only joy but also humour, irony and gaiety and it became the main accent in postmodern culture. There are many funny stories and medieval anecdotes about Franciscans, especially about Brother Juniper.

Nevertheless Franciscan laughter is problematic because of: (1) firstly, distinction joy and laughter spelled out in The Admonitions of St. Francis: " (a) Blessed is that religious who has no pleasure and delight except in the most holy words and deeds of the Lord; (b) And, with these, leads people to the love of God with gladness and joy (Ps. 51:10); (c) Woe to that religious who delights in idle and empty words and leads people to laughter with them" (Armstrong, Hellmann \& Short, vol. I, 1999, p. 135). (2) Secondly, it relates to a very sensetive aspect of St. Francis as the God's Fool. The original model for God's Foolishness, as well as for the sainthood and martyrdom, is represented by Christ himself. St. Francis was already represented in the Middle Ages as alter Christus but in comparison to the Savior saint of Assisi reaches more intensive joy through suffering and humiliation. It's quite compatible with the medieval vision but it presents the image of the saint in lighter colours. By the way, St. Francis in his humility is not only Christ-like but very human as well and even philosophical person as was noted earlier. According to Bateman (1984, p. 187), "Christian humility is the true philosophy". Of course, it is anthropological oriented philosophy, moreover new, postmodern interpretations of the Christ Himself paid attention to His humanity more than His divine nature. These ones were based on the Nag-Hammadi texts; explosion of the apocryphal versions; "Christianity without religion" by D. Bonhoeffer etc. (3) Finally, protestant theologian Harvey Cox announced the coming of the Christ-clown as a manifestation of festivity and fantasy and revival of the true spirit of the early Christianity. Cox appealed in 1969: "Enter Christ the harlequin: the personification of festivity and fantasy in any age that had almost lost both. Coming now in greasepaint and halo, this Christ is able to touch our jaded modern consciousness, as other images of Christ cannot" (Cox, 1969, p. 139). So, if St. Francis is alter Christus he could behave in the same way especially because he embodies the spirit of religious renewal and new monasticism as well. And really, Cox mentions two movements, which had the specific potential of development and realization of the spirit of renovation. These are neomystics and new militants. The neomystics resemble the first Franciscans with their happy poverty, conversing with the birds and angering the pillars of the society. St. Francis of Assisi and the Franciscans appeared in articles of the 1960s also as apostles of joy, festivity and imagination compared to hippies and, possibly, this was one of the most contradictory points. Wesolowski wrote about St. Francis: "He was instrument of celebration. He celebrated creatures, himself, and his God" (Wesolowski, 1982, p. 72).

Not surprisingly Jorge from The Name of the Rose (and really Eco himself) identifies St. Francis as clown and defender of laughter: "You are a clown, like the saint who gave birth to you all" (Eco, 1983, p. 477-478). For Jorge laughter is "defense for the simple", a tool for plebeians, rebels, and kings of fools and, seemingly, Franciscan William accepts this role of the apologist of laughter although in more wide cultural and theological framework. William gives a good summary of Francis's accomplishments: "Francis taught people to look at things from another direction" (Eco, 1983, p. 478). William's position coincides with a recent view of the order that sees its worldly and profane spiritual strategies as a "carnavalized Catholicism". In Coletti's (1988) opinion, 
"William may be the 'Minorite clown', but he can more appropriately be considered a messenger between the center and the margin, hegemony and difference, official and unofficial culture" (Coletti , 1988, p. 154).

These are qualities that distinguish the jester, the clown and the trickster. However, only in God's Fool are they subdued to the religious foundations of personality. St. Francis acts as God's Fool in Green's novel by the same name (1983). Green (1985) wrote: "He (St. Francis) was known for his invariable cheerfulness and the joil de vivre that throbbed in the latest cantilena he had picked up from the troubadours and through who were forever passing through the country" (Green, 1985, p. 16); Green described St. Francis' feelings in terms "irresistible call to joy"; "the supernatural joy"; "the joy of obeying"; "immense joy" (when the saint kissed the leper); "joy of being” etc. Sometimes St. Francis felt special kind of joy that was mad joy.

Green recalls some anecdotes about St. Francis like the episode when the Pope proposed to him to go to pigs and to be their preacher. Francis did it and came back to Innocent III. He was not only laughed at many times (by neighbors, by his former friends etc.) but also the jokes of St. Francis himself "unleashed hysterical laughter" (Green, 1985, p. 38). Even in prison "he smiled, joked, and sometimes even managed to get his companions to laugh" (Green, 1985, p. 48); he danced and sang. So, it contradicts St. Francis' above-mentioned passage about laughter but it corresponds with the postmodern interpretation.

In general Green was far from postmodern poetics and agenda but there was current context in his book, for example when he compared troubadours to young wanderers and hippies, "children of flowers". St. Francis himself urged to the brothers to be like children, for example in The First Letter to the Faithful. But in this case he meant not so much mature mind and hidden wisdom as could be seen in the numerous paintings of Christ-Child as openness to the world, sincerity and joyfulness. It is known about St. Francis' self-identity as novus stultus (new simpleton) or novus pazzus (new madman) at the Pentecost Chapter of 1222. Francis considered himself as ignoras et idiota (Compare the Latin maxim ignoramus et ignorabimus, that means "we do not know and will not know").

St. Francis identified himself as God's Fool and was mocked a lot like archetypical Fool and Christ just as a special kind of Fool. It is said by St. Francis: "And the Lord told me that he wished me to be a new fool in the world, and that he did not want to lead us by any other way than by that wisdom" (Armstrong, Hellmann \& Short, 2001, vol. III, p. 124). A Mirror of the Perfection (Sabatier edition) reproduces words of St. Francis:

It should not be understood or believed, however, that our father, a lover of total maturity and integrity, would have wanted this joy to be shown through laughter or even empty words, when, through this, it is not spiritual joy that is shown but vanity and foolishness. In fact, he abhorred laughter and an idle word to an exceptional degree in a servant of God, since he not only wanted him not to laugh, but not even to give the slightest occasion for others to laugh ... Woe to that religious who delights in idle and empty words and leads people to laughter with them. Nevertheless

by a joyful face he understood the fervor and solicitude, the disposition and readiness of a mind and body to willingly undertake every good work ... That is why he did not want to see a gloomy face, which more often shows laziness, a closed mind, and a body listless for every good work (Armstrong, Hellmann \& Short, 2001, vol. III, p. 343).

St. Francis' joy has been discussed in various Franciscan sources before, especially in the Flowers. Thomas Celano mentions "modest laughter" (risus modestus) of Franciscan brothers in the First Life. Accent that is made here on the distinction between inner and outer joy became especially apparent in Sabatier's text as never before. It was a new phase of the Romantic and sentimental vision of St. Francis in the culture of the 
twentieth century culminated in the postmodern situation.

\footnotetext{
If a servant of God always strives to have and preserve internally and externally the spiritual joy that proceeds from purity of heart and is acquired through the devotion of prayer, the devils could do him no harm ... it must be your primary concern to acquire and preserve these two virtues, to possess internal, as well as external joy. (Armstrong, Hellmann \& Short, 2001, vol. III, p. 342)
}

This passage reminds us of some thoughts of the famous Ukrainian philosopher H.S. Skovoroda. But Skovoroda himself never approached this type of Holy Fool despite the fact that he interpreted Christianity in non-dogmatic terms and also was not stranger to spiritual gaiety, proceeded from his "inward man".

When the central protagonist is a patron of nature, a hero, a troubadour, he can have an element of foolishness within, but which is subdued to more spiritual and less marginal dimensions. But if the Fool is at the center of discourse, it could be a more ambivalent and dangerous way of thinking, from both a medieval and theological position in general.

Foolishness as correlated with childishness can be seen in Francis' hagiography, for example, in an episode with Brother Juniper and children. Brother Juniper has a special place in Franciscanism in general. He was called the "jester of the Lord". He is well-known due to some legends about him, the most amazing of which is, possibly, The Legend of the Pig's Feet. But it relates to the postmodern image of St. Francis himself no less.

But the problem is that Fool is not only mocked but he is mocking and the border between Holy Foolishness, on the one hand, and real stupidity and provocation, on the other hand is very unstable and unclear. There are faces of the Fool as harlequin, clown, acrobat who are not only mocked like stupid men and sympathized like children but mock as well and play.

God's Fool is one of the versions or faces of the same archetype to whom not only buffoon, harlequin, and acrobat belong but also a trickster who has distinctly negative and dangerous elements in his semantic. But God's Fool appeals to marginality and mocking laughter and enhances the problem of relation between St. Francis and Gnosticism, Catharism and non-orthodoxy. In this regard, the postmodern interpretation does not only oppose orthodoxy but also creates an internal contradiction between the secularisation of culture and the sacralisation of laughter.

That potential of freedom and hope, which has been kept in play and carnival, has been realised in the postmodern Divine Comedy. Twentieth century culture, as a whole, demonstrated a keen interest in the concept of the world as representation, not in Schopenhauerian, but rather in the theatrical, more definitely tragicomical sense. If modernism interpreted the world mainly as absurd, filled by despair and disorder, for postmodern culture, this is a farce. God as if makes fun at people who do not notice their own stupidity and arrogance, involves them in the chain of events, that develop in unpredictable and paradoxical way (The Devil and the Ten Commandments, 1962, dir. J. Duvivier). In the postmodern situation, different forms and degrees of irrationality, including madness, have been an object of philosophical reflection, academic interest, art and literature. But sometimes the "consumer society" as a whole is posted as a madhouse, whose inhabitants quite willingly accept the rules of play in this comedy and sometime even take pleasure in doing so (G. Greene's novel The Comedians, 1966, filmed in 1967, dir. P. Glenville). In the movie Ship of Fools (1965, dir. S. Kramer) the title of the famous work by Sebastian Brant is a metaphor for embracing the diversity of defects, errors and 
follies of the Western society on the eve of the Second World War. Fernandel (Simplet, 1942), I. Bergman (Sawdust and Tinsel, 1953; In the Presence of a Clown, 1997), A. Hitchcock (Psycho, 1960), B. Levinson (Rain Man, 1988) Lars von Trier (The Idiots, 1998), in literature K. Kesey (One Flew Over the Cuckoo's Nest, 1962), H. Böll (The Clown, 1963) and others explore authentic and imaginary madness in their films.

Thus, postmodernity subjected the Bible to the same laws of comic effect, which entail inconsistencies, contradictions and deviations from the norm, like any narrative. This approach, of course, was influenced by the European tendency to consider the Bible as literature. In turn, the sacralisation of comedy and laughter reigning therein, is justified and inevitable. But this tendency conflicts with the general trend of postmodernity towards desacralization, intentional profanation and rejection of any idols, especially in the religious sphere.

This contradiction can be resolved in following way. The laughter that both proceeds from God and is shared with Him is the laughter of sympathy; and this is a manifestation of the spiritual, inner joy, from the side of a man. The joy can be understood as a kind of world view and then laughter is not its profanation or debasement, but continuation and natural expression. But laughter can be sneer as well, even irony can express sneer as in the prophetic books of the Old Testament. With or at character of laughter defines the person to whom it's attributed, his place in the Divine comedy, and the character of the deity itself. As carnival personage the Fool is ambivalent. Not accidently he appears sometimes in gloom stories and horror movies (Ghost in the Shell, Laughing Man by J. D. Salinger etc.); he hides the contradiction inside him, as well as any human being, but he enjoys his own duality and his superiority over the spectators, who do not want to admit this ambivalence. He exposes the nakedness of both the world and a man. We understand the God's Fool as the archetypical character who contains actually or potentially a huge set of masks, and versions. From this point of view the negative or positive position depends on his attitude to God. His Lord is God as a ruler of the Divine Comedy or, on the contrary, "Lord of Disorder" as the devil was called in medieval literature.

God, about whom the Christ talks in the parables, is not the God of the Old Testament, whose laughter divides, separates and condemns. On the contrary, joy, which Jesus feels with people and especially with children, is based on His own joy and joy he finds in God and joy God Himself feels. It is not laughter at human beings, but joy which not necessarily expresses itself in laughter but to which laughter is not alien. As K.J. Kuschel (1994) noted "Jesus' laughter is the expression of a freedom for God which bursts bounds and breaks taboos" (Kuschel, 1994, p. 79). God shares such laughter with the clown, trickster, the God's Fool and the righteous man. Skeptical laughter at God can be transformed into joyful and liberating laughter with God like the case of Abraham and Sarah. Such shared laughter is creative; it is the laughter of the creator upon the world's creation, coinciding with the laughter of human joy at the result of creativity. The comic vision has been expressed in this way and it fills the world with optimism, and redemption and also festivity and fantasy about which Cox spoke. But, God's laughter can be directed at the cheater, the real fool and the sinner as well if they neglect Him or sneer at Him. In this case, the Fool's laughter is a sign of his frivolity and lack of thought. It stresses his marginality and provokes his punishment and this punishment can be turned into a carnival event (look at The Idle 'Prentice Executed at Tyburn by William Hogart). To put it in another way, the carnival spirit often reveals itself in rebellion (Dolchino's rebellion in The Name of the Rose). Carnival turns to destruction, revelry, and bacchanalia, which destroy God's trust in man, and then God Himself destroys the rebellious world (The Tower of Babel) and the rebellious peoples who rise against Israel and prophets. Then God seems 
incomprehensible, mysterious, and severe. It will be not surprising to think of God as the mocking tyrant. Even ancient gods were capable of derisive laughter deprived by true humanity. There was no dialogue between God and man. On the contrary, in Christianity the character of laughter depends on these relations. So, this should be a point of the postmodern interpretations of emotions towards religious plots and personages.

Authors of the book St. Francis and the Foolishness of God (1993) defined St Francis' foolishness both in negative (active involvement in the poverty, nakedness, homelessness, and humiliation in the name of Lord) and positive way (unbounded capacity for joy, his sense of ecstatic union with all the things, his sensual delight in the created world, his singing of the Lord's song to all creatures; his sense of the comic and the absurd, his willingness to be the occasion for laughter and amusement, and his gratitude for all things) (Dennis, 1993). But the most important thing is that he keeps a balance between tragedy and comedy, joy and suffering, sainthood and foolishness. It is not surprising that sometimes he is compared with prominent Eastern saints and prophets (Brophy, 1959). Nevertheless, the tradition founded by St. Francis, was based on the main components of western Christocentric spirituality. Possibly, the establishment and development of the Church as a social and political body did not stimulate the full realisation of ideas, which can be revealed in the preaching of Christ and apostles. Franciscans and, to a lesser extent, other mendicant orders revived the optimistic spirituality, although they reflected both the dramatic contradictions of their epoch and the internal ambiguity of Catholic Christianity with its accent on suffering.

\section{Conclusions}

St. Francis maintains this balance despite all postmodern exaggerations because of his joyfulness, which penetrates even his images as a hero, a troubadour, a patron of animals and nature, and a peace-maker, and because of the distinction between mocking laughter and a laughter of sympathy. Of course, various legendary materials confirm this interpretation more than the writings of St. Francis himself (they were not very numerous, so in any case this is a question of interpretation) except, possibly, Canticle of the Creatures, which quite corresponds to the postmodern approach, reflecting man as a living being among other creatures penetrated by joyful vision, which we encounter in environmentalism.

Thus, it can be concluded that in the modern and postmodern interpretations of St. Francis of Assisi the philosophical-anthropological perspective reveals his humanity, which is marked by new visions of Christ himself and Christianity in general in comparison with medieval sources.

Modernity places an accent on the Christian humanism of St. Francis as apologist of the religious and spiritual renewal of the late Middle Ages and the predecessor of the Renaissance. Modernity put forward this saint's more emotional, spiritual, and joyful vision. While his features as poet, mystic and God's troubadour were slightly outlined, postmodernity developed them into more radical interpretations of the Saint of Assisi. Some medieval points were strengthened, first of all an apology of poverty. But the most radical turn happened with respect to an apology of spiritual gaiety and laughter in the context of reforms within the Catholic Church and carnivalisation in the postmodern cultural space.

The final point is that to keep this balance and avoid postmodern contradictions towards Franciscan joy and laughter and the theological approach to these concepts in general, God's Fool should be put at the center of the postmodern Divine Comedy, although it's reasonable to take the necessary criteria in consideration, 
primarily shared or non-shared character of laughter. Overcoming these contradictions is dictated by logic of postmodernity itself.

\section{References}

Armstrong, R. J., Hellmann, J. A. W., \& Short, W. J. (Eds.). (1999-2001). Francis of Assisi: Early documents (Vols. 1-3). Hyde Park, NY: New City Press.

Auerbach, E. (1945). St. Francis of Assisi in Dante's Commedia. Italica, 4(22), 166-179.

Basetti-Sani, G. (1958). Muhammad and St. Francis. Cord, 8, 72-82.

Bateman, J. J. (1984). Further Reflections and Inquiries on the Origins of the Byzantine Renaissance. A Journal of the History of Rhetoric, 2:3, 284-292.

Boff, L. (1982). Saint Francis: A model for human liberation. New York, NY: Crossroad.

Bowers, J. (2009). Capturing the Gravity and Grace of St. Francis of Assisi on Stage: A Meditation on Word and Image. In C. Ho,

B. A. Mulvaney, \& J. K. Downey (Eds.), Finding Saint Francis in literature and art (pp. 149-162). New York, NY: Palgrave Macmillan.

Brophy, L. (1959). St. Francis, Buddha and Confucius. St. Anthony Messenger, 67, 17-19.

Cataldo, L. M. (2007). Religious experience and the transformation of narcissism: Kohutian theory and the life of St. Francis of Assisi. Journal of Religion and Health, 4(46), 527-540.

Chesterton, G. K. (2008). Saint Francis of Assisi. Peabody, MA: Hendrickson Publishers.

Coelho, P. (2012). The juggler of our lady. Retrieved from http://paulocoelhoblog.com/2012/12/23/the-juggler-of-our-lady

Coletti, T. (1988). Naming the rose: Eco, medieval signs and modern theory. Ithaca: Cornell Univ. Press.

Cox, H. (1969). The feast of fools: a theological essay on festivity and fantasy. Cambridge: Harvard Univ. Press.

Cushing, R. C. (1961). Saint Francis and Karl Marx. Friar, 15, 43-48.

Dennis, M. (1993). St. Francis and the foolishness of God. Maryknoll: Orbis Books.

Eco, U. (1983). The name of the rose. San Diego: Harcourt B. Jovanovich.

French, R., \& Cunningham, A. (1996). Before science: the invention of the friars' natural philosophy. Aldershot, Hants; Brookfield, Vt.: Scolar Press.

Frugoni, C. (1998). Francis of Assisi: A life. New York, NY: Continuum.

Green, J. (1985). God's Fool:The life and times of Francis of Assisi. San Francisco: Harper \& Row.

Hoch, A. S. (1987). St. Martin of Tours: His transformation into a chivalric hero and Franciscan ideal. Zeitschrift für Kunstgeschichte, 4(50), 471-482.

Jewett, S. (1957). God's troubadour: The story of Saint Francis of Assisi. New York: Crowell.

Keen, S. (1970). To a dancing God. New York, NY: Harper \& Row.

Kopaczynski, G. (1990). Saint Francis and philosophy. American Catholic Philosophical Quarterly, 2(64), 249-260.

Kuschel, K. J. (1994). Laughter: A theological essay. New York, NY: Continuum.

Lafferty, R. (1911). The philosophy of Dante. Annual Reports of the Dante Society, 30, 1-34.

Maher, M. C. (1978). The heroism of Francis of Assisi. Liturgy, 23, 13.

Matzerath, R. (1963). Pope John, St. Francis and Vatican II. Way, 19, 5-12.

McCann, J. (2009). Constructing Saint Francis for the twenty-first century. In C. Ho, B. A. Mulvaney, \& J. K. Downey (Eds.), Finding Saint Francis in literature and art (pp. 139-148). New York, NY: Palgrave Macmillan.

McElrath, D. (Ed.). (1980). Franciscan Christology: Selected texts, translations and introductory essays. St. Bonaventure, NY: Franciscan Institute, St. Bonaventure University.

McGuire, M. R. (1953). Mediaeval humanism. The Catholic Historical Review, 4(38), 397-409.

Metz, J. B. (1998). Poverty of spirit. New York, NY: Paulist Press.

Peck, G. T. (1980). The fool of God, Jacopone da Todi. University of Alabama Press.

Sabatier, P., \& Bevan, W. L. (1909). The originality of St. Francis of Assisi. The Sewanee Review, 1(17), 51-65.

Salinger, J. D. (1981). Franny and Zooey. Toronto, New York, London, Sydney: Bantam Books.

Scheler, M. (2008). The nature of sympathy. Piscataway, NJ: Transaction Publishers.

Scheler, M. (1973). Selected philosophical essays. Evanston, Northwestern University Press.

Schiffers, N. (1974). The humor of John XXIII. In J. B. Metz, \& J. P. Jossua (Eds.), Theology of joy (pp. 126-133). New York, NY: Herder \& Herder. 
Sorrell, R. D. (1988). St. Francis of Assisi and nature: tradition and innovation in Western Christian attitudes toward the environment. New York, NY: Oxford University Press.

Tolan, J. (2009). Saint Francis and the Sultan: The Curious History of a Christian-Muslim Encounter. Oxford; New York, NY: Oxford University Press.

Vanhoozer, K. J. (Ed.). (2003). The Cambridge companion to postmodern theology. Britain:Cambridge University Press.

Ward, G. (Ed.). (2001). The Blackwell companion to postmodern theology. Oxford: Blackwell Publishers.

Wesolowski, L. (1982). The hippie from Assisi. Sisters, 54, 72-75. 